\title{
Job Demands And Its Effects On Health: A Study On Indian Loco-Pilots (Railway Drivers)
}

\author{
Rajesh Ranjan ${ }^{1}$, T. Prasad ${ }^{2}$ \\ ${ }^{1}$ Fellow (Ph.D. Scholar), ${ }^{2}$ Associate Professor, \\ National Institute of Industrial Engineering (NITIE), Mumbai
}

\begin{abstract}
Indian railway drivers (loco-pilots) are working in an environment over which they have no control whatsoever and are an atmosphere that wrecks their schedules, disrupts their home life, makes social activities and regular breaks very hard to plan. This research study aim to assess the job demands and its various effect on health (for ex; sleeping troubles, burnout, stress, depressive symptoms and job satisfaction) faced by the Indian railway drivers (loco-pilots) using the COPSOQ (Copenhagen Psychosocial Questionnaire). Moderating effects of personality trait (in this study it is self efficacy) between job demands and its various effect on health also find out. Sleeping troubles, burnout, stress, depressive symptoms and job satisfaction are projected as intended outcomes of job demand.
\end{abstract}

Keywords: Railway driver, job demand, sleeping trouble, burnout, stress, job satisfaction, self efficacy.

\section{INTRODUCTION OF RAILWAY DRIVERS (LOCO-PILOTS)}

The railway driver is exposed to a demanding psychosocial work environment, which includes solitary work, limited opportunities for social contact and a heavy responsibility for operating the train (in terms of both safety and adhering to the timetable) (Ranjan, R. and Prasad, T., 2013). Job of railway driver is perceived as very stressful, and stress is here the result of conflict demands on driver, and low level of control by driver on these demands and circumstances, for example time pressure, long shifts, responsibility for security of passengers for instance (Dorn, 2003).

\section{JOB DEMANDS}

Job demands have been defined as those aspects of work that require sustained physical or psychological effort or skills (Bakker and Demerouti, 2007). Job demands are not always negative, but may become stressors when they require a high degree of effort, in which case they can be associated with costs such as burnout or depression (Schaufeli and Bakker, 2004).

\section{JOB STRESS AND JOB SATISFACTION}

Varca (1999) argued that stress is defined as the perception of a discrepancy between environmental demands (stressors) and individual capacities to fill these demands. Stress often shows high dissatisfaction among the employees, job mobility, burnout, poor work performance and less effective interpersonal relations at work (Mansor et al., 2003). Karasek (1979) developed a model that predicts the mental strain of a job, based on the work demands and the decision latitude. The main finding from this study is that a combination of low decision latitude and high job demands results in heavy mental strain. Over the time this leads to job dissatisfaction. Sullivan and Bhagat (1992) concluded that relationship between job stress and job satisfaction are inversely related. This means a higher level of job stress will cause a lower level of job satisfaction.

\section{JOB STRESS OF LOCO-PILOTS (RAILWAY DRIVERS) IN INDIA}

For Railways' drivers operating on long distance routes, overnight stays in various locations will be necessary. Furthermore, it can be stressful, as delays and hazards on the track are not uncommon. His cab of the train should be relatively comfortable but it may be quite cold, hot and noisy (Singh Ravi Kant, 2008). Railway drivers (loco-pilots) in India are working in an environment over which they have no control whatsoever and are an atmosphere that wrecks their schedules, disrupts their home life, makes social activities and regular breaks very hard to plan. Report of Research Designs and Standard Organization (RDSO), (1997) revealed higher level of stress in railway driver's job in comparison to other job categories like assistant station masters, train examiners and office clerks. 


\section{BURNOUT}

Burnout is commonly defined as the negative consequences of exposure to chronic job stress and is closely related to depression (Shirom, et al., 2005).

\section{THE MODERATING VARIABLE: PERSONALITY TRAITS (SELF EFFICACY)}

Bandura's (1977) self-efficacy theory proposes that if a person has high self-efficacy (i.e. belief to his/her ability in executing a course of action) this will not invoke his/her negative cognitive thoughts. Application of this theory in a occupational stress model shows that if a person has high self-efficacy (i.e. belief to his/her ability to manage emotions) this will effectively decrease his/her job stressors, and increase his/her emotional health and lower level of psychological stress.

\section{CONCEPT OF HEALTH}

The concept of health was defined by the World Health Organization (WHO) in 1948 as "a state of complete physical, mental, and social well-being and not merely the absence of disease or infirmity". During the Ottawa Charter for Health Promotion conference in 1986, the WHO attempted to provide a definition of health promotion "optimal health is a balance of physical, emotional, social, spiritual, and intellectual health". WHO has proposed that mental health is a state of well-being in which the individual realizes his or her own abilities, can cope with the normal stresses of life, can work productively and fruitfully, and is able to make a contribution to his or her community (WHO, 2005). Poor mental health has a significant impact on family and/or job satisfaction.

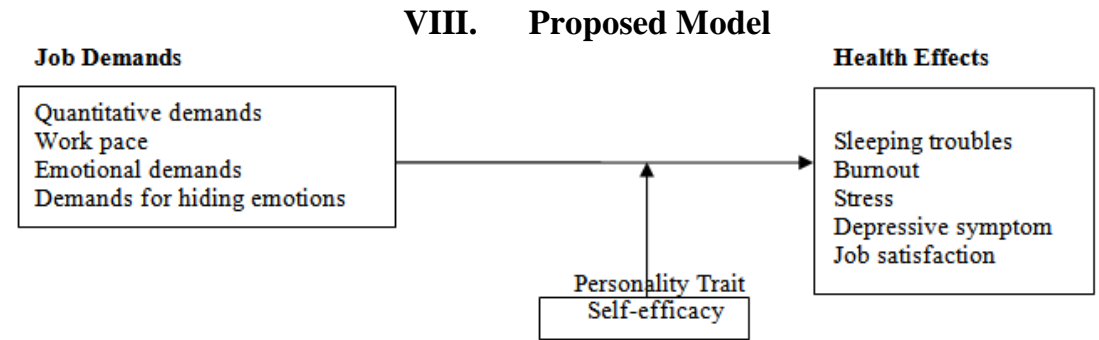

Fig; 1: Proposed model

This model is based on the structure of DCS (Demand-Control-Support model, Karasek and Theorell 1990). This model proposes that job demands are all proposed to have main effect relationships on burnout, stress, sleeping troubles, depressive symptoms and job satisfaction. It is also proposed that individual differences (personality trait-self efficacy) may moderate the relationship between job demands and outcomes (effects on health). Karasek (1979), notified job demands as a division of all potential work stressors, particularly "psychological stressors involved in accomplishing the work load, stressors related to unexpected tasks and stressors of job related personal conflict". According to Karasek and Theorell (1990), psychological demands have both a quantitative and a qualitative component. The psychological demands as a matter of "workload", or how "hard, fast and much" an employee works. This work includes, deadlines, productivity (units per hour), reporting (number per week), as well as conflicting demands.Personality traits (self efficacy) are found to be a moderator between job demands and its various effect on health. It was suggested that individuals with higher self efficacy will be able to cope up with obstacles in a better way as compared to those who have lower self efficacy. So it can be assumed that individuals with higher self efficacy will be able to handle demands (job and family) in a better way. Overall this study presents an integrated model for describing the relationships between job demands and its various effect on health faced by the railway drivers (loco-pilots) in India. Moderating affects of personality trait (self efficacy) between variables were also find out.

\section{RESEARCH METHODOLOGY}

This study uses descriptive survey design. Data was collected by using "Copenhagen psychosocial Questionnaire-II" (long version). A pilot survey was conducted to test the reliability and validity through a COPSOQ-II filled by the participants.

\section{IX.1 Sampling Design}

This study adopted a cluster-random sampling approach. The samples for this pilot-study were Indian railway's drivers working in Gaya under Mugalsarai Division, ECR-Hajipur and Chhapra under Varanasi Division, NER-Gorakhpur. Questionnaire was personally distributed among them.

\section{IX.2 Measurement of the Job Demands and its Various Effect on Health}


For measuring job demands, the COPSOQ-II scale includes four scales- quantitative demands, emotional demands, demands for hiding emotions and work pace were used. For measuring health effects, the COPSOQ-II scale includes five scales - sleeping troubles, burnout, stress and depressive symptoms) and "job satisfaction" (single scale) were used. For measuring self efficacy "self efficacy" (single scale) were used. The scales are based on the long version of the COPSOQ-II (Kristensen et al., 2010). In most cases the questions have five response options. In these cases the weights are: $0,25,50,75$, and 100 . The scale value is calculated as the simple average. The direction of the score follows the label of the scale; that is, a high score indicates high demands, and so on

\section{STATISTICAL ANALYSIS}

The statistical analysis was carried out with the help of SPSS-programme (Statistical Package for Social Science). Initially, the demographic data was displayed and the reliability analysis with Cronbach's alpha coefficient was performed to identify the reliability of this survey and Pearson correlation and Regression analysis was performed to identify the relationship between variables.

\section{X.1 Demographic Variables}

The demographic questions used to understand the characteristics of the participants. Participants were asked to report demographic information including age, designation, education, salary, duration in present job, place of posting, marital status, time spent in work and household tasks per week and general health perception etc.Researcher approached 150 Loco-pilots; out of which 92 (61\%) Loco-pilots (railway drivers) responded. All the participants of this study are male, as very few females (about 50 women train drivers) are employed as railway's drivers in India (Surekha Yadav joined in 1986 is the first women driver of Indian railway). Out of 92 railway drivers $01(1.1 \%)$ respondent is Assistant Loco Pilot, 12 (13\%) respondents are Assistant Loco Pilot Goods, 11 (12\%) respondents are Assistant Loco Pilot Passenger, 23 (25\%) respondents are Loco Pilot Goods, $08(8.7 \%)$ respondents are Loco Pilot Passenger, 17 (18.5\%) respondents are Loco Pilot Mail and 18 (19.6\%) respondents are Loco Pilot Shunting and $02(2.2 \%)$ respondents are Crew-controller. Amongst the respondents $01(1.1 \%)$ is in age of $<=20$ years, $15(16.3 \%)$ are in between age group 26-30 years, $24(26.1 \%)$ are in between age group 31-35 years, $16(17.4 \%)$ are in between age group 36-40 years, $18(19.6 \%)$ are in between age group 41-45 years, $12(13 \%)$ are in between age group 46-50 years and $06(6.5 \%)$ are in between age of $>=50$ years. Out of 92 respondents $03(3.3 \%)$ are working as railway driver in between from 0-5 years, $25(27.2 \%)$ are in between from 6-10 years, $16(17.4 \%)$ are in between from 11-15 years, 15 (16.3\%) are in between from 16-20 years and $33(35.9 \%)$ are from more than 20 years. Amongst the respondents $01(1.1 \%)$ is completed Matric, 25 (27.2) are completed ITI, 02 (2.2\%) are completed both ITI and Intermediate, 22 (23.9) are completed Diploma in Engineering, $05(5.4 \%)$ are completed both ITI and Diploma in Engineering, 02 (2.2\%) are completed Graduation, $32(34.8 \%)$ are completed both ITI and Graduation, $01(1.1 \%)$ is completed Post-Graduation and 02 (2.2\%) are completed both ITI and Post-Graduation. All the 92 respondents (100\%) are found to be married. Amongst the respondents $21(22.8 \%)$ are told they always miss out quality time with family and friends because of pressure of work, $12(13 \%)$ respondents are told they often miss out quality time with family and friends because of pressure of work, $34(37 \%)$ response as sometimes miss out quality time with family and friends because of pressure of work, $20(21.7 \%)$ response as rarely miss out quality time with family and friends because of pressure of work and $05(5.4 \%)$ response as never miss out quality time with family and friends because of pressure of work.

\section{X.2 Descriptive Statistics of the Variables}

The filled questionnaire data was analyzed using the Statistical Package for Social Science (SPSS 20 version) software. Table-1 explores the descriptive statistics of different variables under study.

Table -1: Summary: Descriptive Statistics of the variables

\begin{tabular}{|c|l|c|c|c|c|c|}
\hline $\begin{array}{c}\text { Sr. } \\
\text { No }\end{array}$ & \multicolumn{1}{|c|}{ Variable } & $\begin{array}{c}\text { No. of } \\
\text { Items }\end{array}$ & Minimum & Maximum & Mean & Std. Deviation \\
\hline 1 & Quantitative Demands & 4 & 0 & 275 & 33.70 & 73.04 \\
\hline 2 & Work Pace & 3 & 0 & 300 & 30.43 & 65.76 \\
\hline 3 & Emotional Demands & 4 & 75 & 375 & 297.83 & 68.80 \\
\hline 4 & Demands for Hiding Emotions & 3 & 75 & 275 & 212.77 & 47.24 \\
\hline 5 & Sleeping Troubles & 4 & 0 & 400 & 98.64 & 74.15 \\
\hline 6 & Burnout & 4 & 0 & 400 & 113.59 & 84.46 \\
\hline 7 & Stress & 4 & 0 & 400 & 97.55 & 68.04 \\
\hline 8 & Depressive symptoms & 4 & 0 & 275 & 81.30 & 49.25 \\
\hline 9 & Job satisfaction & 4 & 100 & 250 & 144.57 & 36.65 \\
\hline 10 & Self efficacy & 6 & 150 & 600 & 535.05 & 66.71 \\
\hline & & Total=40 & & & & \\
\hline
\end{tabular}


It can be inferred from table-1, that the mean value of emotional demands is 297.83, which indicates that most of the respondents are found to be high emotional demands. The mean value of demands for hiding emotions is 212.77, which indicates that most of the respondents are found to be high demands for hiding emotions. The mean value of quantitative demands is 33.70, which indicates that most of the respondents are found to be low quantitative demands. The mean value of work pace is 30.43 , which indicates that most of the respondents are found to be low work pace. It can be inferred from table-1, that the mean value of sleeping troubles is 98.64, which indicates that most of the respondents are found to be some sleeping troubles. The mean value of burnout is 113.59 , which indicates that most of the respondents are found to be some burnout. The mean value of depressive symptoms is 81.30 , which indicates that most of the respondents are found to be some depressive symptoms. The mean value of job satisfaction is 144.57 , which indicates that most of the respondents are found to be lower job satisfaction. The mean value of personality trait (self-efficacy) is 535.05, which indicates that most of the respondents are found to be very high self- efficacy.

\section{X.3 Cronbach's Alpha (a) Reliability Analysis of Scales}

The filled data was tested for Cronbach's Alpha $(\alpha)$ reliability with a sample of 92 Indian railway drivers respondents.

Table-2: Summary: Cronbach's Alpha Reliability ( $\alpha$ ) Analysis

\begin{tabular}{|c|l|c|c|c|}
\hline $\begin{array}{c}\text { Sr. } \\
\text { No }\end{array}$ & $\begin{array}{c}\text { Scale } \\
\text { Items }\end{array}$ & $\begin{array}{c}\text { Cronbach's Alpha Values } \\
\text { of Original Scales }\end{array}$ & $\begin{array}{c}\text { Cronbach's Alpha } \\
\text { Values from the current } \\
\text { study }\end{array}$ \\
\hline 1 & Quantitative Demands & 4 & 0.82 & 0.83 \\
\hline 2 & Work Pace & 3 & 0.84 & 0.92 \\
\hline 3 & Emotional Demands & 4 & 0.87 & 0.69 \\
\hline 4 & Demands for Hiding Emotions & 3 & 0.57 & 0.53 \\
\hline 5 & Sleeping Troubles & 4 & 0.86 & 0.92 \\
\hline 6 & Burnout & 4 & 0.83 & 0.95 \\
\hline 7 & Stress & 4 & 0.81 & 0.94 \\
\hline 8 & Depressive symptoms & 4 & 0.76 & 0.61 \\
\hline 9 & Job satisfaction & 4 & 0.82 & 0.79 \\
\hline 10 & Self efficacy & 6 & 0.80 & \\
\hline & & Total=40 & & \\
\hline
\end{tabular}

\section{X.4 Correlation Analysis between Variables}

The coefficient of correlation expresses the degree of linear relationship between the variables. The closer to zero (0) the coefficient, the less the relationship; the closer to one (1), the greater the relationship. A negative (-) sign indicates that the variables are inversely related and if there is no sign, it indicates that the variables are positively related. To obtain an idea of relationships between all research variables, Pearson correlation coefficients were computed, and are presented in table-3.

Table-3: Correlation between Variables

\begin{tabular}{|c|c|c|c|c|c|c|c|c|c|c|c|}
\hline $\mathrm{Sr}$ & Pearson Correlation & 1 & 2 & 3 & 4 & 5 & 6 & 7 & 8 & 0 & 11 \\
\hline 1 & Quantitative Demands & 1 & & & & & & & & & \\
\hline 2 & Work Pace & $\begin{array}{l}.64 \\
.00\end{array}$ & 1 & & & & & & & & \\
\hline 3 & Emotional Demands & $\begin{array}{l}-.59 \\
.00\end{array}$ & $\begin{array}{c}-.53 \\
.00\end{array}$ & 1 & & & & & & & \\
\hline 4 & Demands for Hiding Emotions & $\begin{array}{l}-.34 \\
.00\end{array}$ & $\begin{array}{c}-.20 \\
.04\end{array}$ & $\begin{array}{l}.47 \\
.00\end{array}$ & 1 & & & & & & \\
\hline 5 & Sleeping Troubles & $\begin{array}{l}.50 \\
.00 \\
\end{array}$ & $\begin{array}{l}.47 \\
.00 \\
\end{array}$ & $\begin{array}{c}-.39 \\
.00\end{array}$ & $\begin{array}{l}-.27 \\
.00\end{array}$ & 1 & & & & & \\
\hline 6 & Burnout & $\begin{array}{l}.52 \\
.00\end{array}$ & $\begin{array}{l}.57 \\
.00\end{array}$ & $\begin{array}{c}-.39 \\
.00\end{array}$ & $\begin{array}{c}-.22 \\
.03\end{array}$ & $\begin{array}{l}.88 \\
.00\end{array}$ & 1 & & & & \\
\hline 7 & Stress & $\begin{array}{l}.56 \\
.00\end{array}$ & $\begin{array}{l}.55 \\
.00\end{array}$ & $\begin{array}{c}-.44 \\
.00\end{array}$ & $\begin{array}{l}-.18 \\
.07\end{array}$ & $\begin{array}{l}.83 \\
.00\end{array}$ & $\begin{array}{l}.81 \\
.00\end{array}$ & 1 & & & \\
\hline 8 & Depressive symptoms & $\begin{array}{l}.49 \\
.00\end{array}$ & $\begin{array}{l}.48 \\
.00\end{array}$ & $\begin{array}{c}-.48 \\
.00\end{array}$ & $\begin{array}{l}-.18 \\
.08\end{array}$ & $\begin{array}{l}.58 \\
.00\end{array}$ & $\begin{array}{l}.58 \\
.00\end{array}$ & $\begin{array}{l}.70 \\
.00\end{array}$ & 1 & & \\
\hline 9 & Job satisfaction & $\begin{array}{c}-.29 \\
.00\end{array}$ & $\begin{array}{c}-.28 \\
.00\end{array}$ & $\begin{array}{l}.17 \\
.10\end{array}$ & $\begin{array}{l}.08 \\
.40\end{array}$ & $\begin{array}{c}-.12 \\
.24\end{array}$ & $\begin{array}{l}-.18 \\
.07\end{array}$ & $\begin{array}{c}-.23 \\
.02\end{array}$ & $\begin{array}{l}-.23 \\
.02\end{array}$ & 1 & \\
\hline 10 & Self efficacy & $\begin{array}{l}-.58 \\
.00 \\
\end{array}$ & $\begin{array}{c}.24 \\
.01 \\
\end{array}$ & $\begin{array}{l}.33 \\
.00 \\
\end{array}$ & $\begin{array}{l}.12 \\
.22 \\
\end{array}$ & $\begin{array}{r}-.15 \\
.13 \\
\end{array}$ & $\begin{array}{c}.18 \\
.08 \\
\end{array}$ & $\begin{array}{r}-.20 \\
.04 \\
\end{array}$ & $\begin{array}{l}-.30 \\
.00 \\
\end{array}$ & $\begin{array}{l}.11 \\
.29 \\
\end{array}$ & 1 \\
\hline
\end{tabular}

(Sig. $\mathrm{p}=0.05)$

$(\mathrm{N}=92)$

\section{X.4.1 Correlations between Quantitative demands and other Variables}

The Pearson correlation value shown in above table-3 reveals positive correlation between quantitative demands and work pace, sleeping troubles, burnout, stress and depressive symptoms. It indicates 
that, when quantitative demands increases or more then work pace, sleeping troubles, burnout, stress and depressive symptoms also increases or more. At the same time negative (inverse) correlation between quantitative demands and self-efficacy with coefficient value of $\mathrm{r}=-.58$ decreases the quantitative demands and hence decreases the work pace, sleeping troubles, burnout, stress and depressive symptoms. It indicates that negative (inverse) correlation between quantitative demands and self-efficacy worked as moderator between quantitative demands and work pace, sleeping troubles, burnout, stress and depressive symptoms. The Pearson correlation value shown in above table-3 reveals negative (inverse) correlation between quantitative demands and emotional demands, demands for hiding emotions and job satisfaction. It indicates that, when quantitative demands increases or more then emotional demands, demands for hiding emotions and job satisfaction decreases. At the same time negative (inverse) correlation between quantitative demands and self-efficacy with coefficient value of $r=-.58$ decreases the quantitative demands and hence increases the emotional demands, demands for hiding emotions and job satisfaction. It indicates that negative (inverse) correlation between quantitative demands and self-efficacy worked as moderator between quantitative demands and emotional demands, demands for hiding emotions and job satisfaction.

\section{X.4.2 Correlations between Work pace and all other Variables}

The Pearson correlation value shown in above table- 3 reveals positive correlation between work pace and quantitative demands, sleeping troubles, burnout, stress and depressive symptoms. It indicates that, when work pace increases or more then quantitative demands, sleeping troubles, burnout, stress and depressive symptoms also increases or more. At the same time negative (inverse) correlation between work pace and selfefficacy with coefficient value of $r=-.24$ decreases the work pace and hence decreases the quantitative demands, sleeping troubles, burnout, stress and depressive symptoms. It indicates that negative (inverse) correlation between work pace and self-efficacy worked as moderator between work pace and quantitative demands, sleeping troubles, burnout, stress and depressive symptoms. The Pearson correlation value shown in above table-3 reveals negative (inverse) correlation between work pace and emotional demands, demands for hiding emotions and job satisfaction. It indicates that, when work pace increases or more then emotional demands, demands for hiding emotions and job satisfaction decreases. At the same time negative (inverse) correlation between work pace and self-efficacy with coefficient value of $r=-.24$ decreases the work pace and hence increases the emotional demands, demands for hiding emotions and job satisfaction. It indicates that negative (inverse) correlation between work pace and self-efficacy worked as moderator between work pace and emotional demands, demands for hiding emotions and job satisfaction

\section{X.4.3 Correlations between Emotional demands and other variables}

The Pearson correlation value shown in above table- 3 reveals positive correlation between emotional demands and demands for hiding emotions. It indicates that, when emotional demands increases or more then demands for hiding emotions also increases or more. Whenever emotional demands decreases or becomes low, positive correlation between self-efficacy with coefficient value of $r=0.33$ and emotional demands increase the emotional demands and hence increases the demands for hiding emotions. It indicates that positive correlation between emotional demands and self-efficacy worked as moderator between emotional demands and demands for hiding emotions. The Pearson correlation value shown in above table-3 reveals negative (inverse) correlation between emotional demands and quantitative demands, work pace, sleeping troubles, burnout, stress and depressive symptoms. It indicates that, when emotional demands decreases or low then quantitative demands, work pace, sleeping troubles, burnout, stress and depressive symptoms increases. At the same time positive correlation between emotional demands and self-efficacy with coefficient value of $r=0.33$ increases the emotional demands and hence decreases the quantitative demands, work pace, sleeping troubles, burnout, stress and depressive symptoms. It indicates that positive correlation between emotional demands and selfefficacy worked as moderator between emotional demands and quantitative demands, work pace, sleeping troubles, burnout, stress and depressive symptoms.

\section{X.4.4 Correlations between Demands for hiding emotions and other variables}

The Pearson correlation value shown in above table-3 reveals positive correlation between demands for hiding emotions and emotional demands. It indicates that, when demands for hiding emotions increases or more then emotional demands also increases or more. The Pearson correlation value shown in above table-3 reveals negative (inverse) correlation between demands for hiding emotions and quantitative demands, work pace, sleeping troubles and burnout. It indicates that, when demands for hiding emotions decreases or low then quantitative demands, work pace, sleeping troubles and burnout increases. 


\section{X.5 Regression Analysis}

The goal of linear regression is to find the causal relationship between the variables. Regression analysis describes the value of the respondents in terms of $\mathbf{R}$ (Correlation Co-efficient) and $\mathbf{R}^{\mathbf{2}}$ (co-efficient determination). $\mathrm{R}$ and $\mathrm{R}^{2}$ can vary from 0 to 1 . Values near 1 mean strong causal relationship between variables, while values near 0 mean there is very little relationship between variables.

\section{X.5.1 Regression Analysis of Sleeping troubles on Job Demands with Moderating variable Self efficacy} Model Summary

\begin{tabular}{|c|c|c|c|c|c|c|c|c|c|}
\hline \multirow{2}{*}{$\begin{array}{l}\text { Mod } \\
\text { el }\end{array}$} & \multirow[t]{2}{*}{$\mathrm{R}$} & \multirow{2}{*}{$\begin{array}{c}\mathrm{R} \\
\text { Square }\end{array}$} & \multirow{2}{*}{$\begin{array}{c}\text { Adjusted R } \\
\text { Square }\end{array}$} & \multirow{2}{*}{$\begin{array}{l}\text { Std. Error of } \\
\text { the Estimate }\end{array}$} & \multicolumn{5}{|c|}{ Change Statistics } \\
\hline & & & & & $\begin{array}{l}\text { R Square } \\
\text { Change }\end{array}$ & $\begin{array}{c}\mathrm{F} \\
\text { Chang } \\
\mathrm{e}\end{array}$ & $\begin{array}{l}d \\
f \\
1\end{array}$ & $\begin{array}{l}d \\
f \\
2\end{array}$ & $\begin{array}{c}\text { Sig. F } \\
\text { Change }\end{array}$ \\
\hline 1 & $\begin{array}{l}. \\
5 \\
5 \\
\text { a }\end{array}$ & .30 & .26 & 63.53 & .30 & 7.59 & 5 & $\begin{array}{l}8 \\
6\end{array}$ & .00 \\
\hline 2 & $\begin{array}{l}. \\
5 \\
6 \\
b\end{array}$ & .32 & .27 & 63.18 & .02 & 1.94 & 1 & $\begin{array}{l}8 \\
5\end{array}$ & .05 \\
\hline
\end{tabular}

a. Predictors: (Constant), Demands for hiding emotions, Work pace, Emotional demands, Quantitative demands. b. Predictors: (Constant), Demands for hiding emotions, Work pace, Emotional demands, Quantitative demands, Personality (Self efficacy).

\section{Dependent Variable: Sleeping troubles}

Model 1 (without the Moderator)

It is found from the model summary $R(0.55), R^{2}(0.30)$ and $F(7.59)$ value explains that there is causal relationship between predictors independent variables (job demands) and dependent variable (sleeping troubles). These value indicates that the correlation between predictors job demands and sleeping troubles is significant and the linear regression of sleeping troubles on demands at work is also significant. It means sleeping troubles is cause-and-effect of job demands.

\section{Model 2 (with the Moderator)}

The changed $\mathrm{R}^{2}(0.02)$ and $\mathrm{F}$ (1.94) value from model summary indicating that there is potentially significant moderation between job demands and sleeping troubles on personality trait (self efficacy) and hence the proposed model is significant.

\section{X.5.2 Regression Analysis of Burnout on Job Demands with Moderating variable Self efficacy} Model Summary

\begin{tabular}{|c|c|c|c|c|c|c|c|c|c|}
\hline \multirow{2}{*}{$\begin{array}{l}\text { Mo } \\
\text { del }\end{array}$} & \multirow[t]{2}{*}{$\mathrm{R}$} & \multirow{2}{*}{$\begin{array}{l}\mathrm{R} \\
\text { Squar } \\
\mathrm{e}\end{array}$} & \multirow{2}{*}{$\begin{array}{l}\text { Adjusted R } \\
\text { Square }\end{array}$} & \multirow{2}{*}{$\begin{array}{l}\text { Std. Error of } \\
\text { the Estimate }\end{array}$} & \multicolumn{5}{|c|}{ Change Statistics } \\
\hline & & & & & $\begin{array}{l}\text { R Square } \\
\text { Change }\end{array}$ & $\begin{array}{c}\mathrm{F} \\
\text { Chang } \\
\mathrm{e}\end{array}$ & $\begin{array}{l}\mathrm{d} \\
\mathrm{f} \\
1\end{array}$ & $\begin{array}{l}\mathrm{d} \\
\mathrm{f} \\
2\end{array}$ & $\begin{array}{l}\text { Sig. F } \\
\text { Change }\end{array}$ \\
\hline 1 & $\begin{array}{l} \\
6 \\
0 \\
\mathrm{a}\end{array}$ & .36 & .33 & 69.02 & .36 & 10.05 & 5 & $\begin{array}{l}8 \\
6\end{array}$ & .00 \\
\hline 2 & $\begin{array}{l}\dot{6} \\
1 \\
\mathrm{~b}\end{array}$ & .37 & .33 & 69.00 & .01 & 1.03 & 1 & $\begin{array}{l}8 \\
5\end{array}$ & .03 \\
\hline
\end{tabular}

a. Predictors: (Constant), Demands for hiding emotions, Work pace, Emotional demands, Quantitative demands. b. Predictors: (Constant), Demands for hiding emotions, Work pace, Emotional demands, Quantitative demands, Personality (Self efficacy).

\section{Dependent Variable: Burnout}

Model 1 (without the Moderator)

It is found from the model summary $R(0.60), R^{2}(0.36)$ and $F(10.05)$ value explains that there is causal relationship between predictors independent variables (job demands) and dependent variable (burnout). These value indicates that the correlation between predictors job demands and burnout is significant and the linear regression of burnout on job demands is also significant. It means burnout is cause-and-effect of job demands. 


\section{Model 2 (with the Moderator)}

The changed $\mathrm{R}^{2}(0.01)$ and $\mathrm{F}(1.03)$ value from model summary indicating that there is potentially significant moderation between job demands and burnout on personality trait (self efficacy and core self evaluation) and hence the proposed model is significant.

X.5.3 Regression Analysis of Stress on Job Demands with Moderating variable Self efficacy Model Summary

\begin{tabular}{|c|c|c|c|c|c|c|c|c|c|}
\hline \multirow{2}{*}{$\begin{array}{l}\text { Mod } \\
\text { el }\end{array}$} & \multirow[t]{2}{*}{$\mathrm{R}$} & \multirow{2}{*}{$\begin{array}{c}\mathrm{R} \\
\text { Square }\end{array}$} & \multirow{2}{*}{$\begin{array}{l}\text { Adjusted R } \\
\text { Square }\end{array}$} & \multirow{2}{*}{$\begin{array}{l}\text { Std. Error of } \\
\text { the Estimate }\end{array}$} & \multicolumn{5}{|c|}{ Change Statistics } \\
\hline & & & & & $\begin{array}{l}\text { R Square } \\
\text { Change }\end{array}$ & $\begin{array}{c}\mathrm{F} \\
\text { Chang } \\
\mathrm{e}\end{array}$ & $\begin{array}{l}d \\
f \\
1\end{array}$ & $\begin{array}{l}d \\
f \\
2\end{array}$ & $\begin{array}{c}\text { Sig. F } \\
\text { Change }\end{array}$ \\
\hline 2 & $\begin{array}{l}.6 \\
3^{b}\end{array}$ & .40 & .36 & 54.28 & .01 & 1.65 & 1 & $\begin{array}{l}8 \\
5\end{array}$ & .02 \\
\hline
\end{tabular}

a. Predictors: (Constant), Demands for hiding emotions, Work pace, Emotional demands, Quantitative demands. b. Predictors: (Constant), Demands for hiding emotions, Work pace, Emotional demands, Quantitative demands, Personality (Self efficacy).

\section{Dependent Variable: Stress}

\section{Model 1 (without the Moderator)}

It is found from the model summary $R(0.62), R^{2}(0.39)$ and $F(11.17)$ value explains that there is causal relationship between predictors independent variables (job demands) and dependent variable (stress). These value indicates that the correlation between predictors job demands and stress is significant and the linear regression of stress on job demands is also significant. It means stress is cause-and-effect of job demands.

\section{Model 2 (with the Moderator)}

The changed $\mathrm{R}^{2}(0.01)$ and $\mathrm{F}(1.65)$ value from model summary indicating that there is potentially significant moderation between job demands and stress on personality trait (self efficacy) and hence the proposed model is significant.

\section{X.5.4 Regression Analysis of Depressive symptoms on Job Demands with Moderating variable Self efficacy} Model Summary

\begin{tabular}{|c|c|c|c|c|c|c|c|c|c|}
\hline \multirow{2}{*}{$\begin{array}{l}\text { Mod } \\
\text { el }\end{array}$} & \multirow[t]{2}{*}{$\mathrm{R}$} & \multirow{2}{*}{$\begin{array}{c}\mathrm{R} \\
\text { Square }\end{array}$} & \multirow{2}{*}{$\begin{array}{c}\text { Adjusted R } \\
\text { Square }\end{array}$} & \multirow{2}{*}{$\begin{array}{l}\text { Std. Error of } \\
\text { the Estimate }\end{array}$} & \multicolumn{5}{|c|}{ Change Statistics } \\
\hline & & & & & $\begin{array}{l}\text { R Square } \\
\text { Change }\end{array}$ & $\begin{array}{c}\text { F } \\
\text { Chang } \\
\text { e }\end{array}$ & $\begin{array}{l}d \\
f \\
1\end{array}$ & $\begin{array}{l}\mathrm{d} \\
\mathrm{f} \\
2\end{array}$ & $\begin{array}{c}\text { Sig. F } \\
\text { Change }\end{array}$ \\
\hline 1 & $\begin{array}{l} \\
5 \\
7 \\
\text { a }\end{array}$ & .32 & .28 & 41.42 & .32 & 8.53 & 5 & $\begin{array}{l}8 \\
6\end{array}$ & .00 \\
\hline 2 & $\begin{array}{l} \\
5 \\
8 \\
\text { b }\end{array}$ & .34 & .29 & 41.57 & .02 & .35 & 1 & $\begin{array}{l}8 \\
5\end{array}$ & .05 \\
\hline
\end{tabular}

a. Predictors: (Constant), Demands for hiding emotions, Work pace, Emotional demands, Quantitative demands. b. Predictors: (Constant), Demands for hiding emotions, Work pace, Emotional demands, Quantitative demands, Personality (Self efficacy).

\section{Dependent Variable: Depressive symptoms \\ Model 1 (without the Moderator)}

It is found from the model summary $\mathrm{R}(0.57), \mathrm{R}^{2}(0.32)$ and $\mathrm{F}(8.53)$ value explains that there is causal relationship between predictors independent variables (job demands) and dependent variable (depressive symptoms). These value indicates that the correlation between predictors job demands and depressive symptoms is significant and the linear regression of depressive symptoms on job demands is also significant. It means depressive symptoms is cause-and-effect of job demands.

\section{Model 2 (with the Moderator)}

The changed $\mathrm{R}^{2}(0.02)$ and $\mathrm{F}(0.35)$ value from model summary indicating that there is potentially significant moderation between job demands and depressive symptoms on personality trait (self efficacy) and hence the proposed model is significant. 


\section{X.5.5 Regression Analysis of Job satisfaction on Job Demands with Moderating variable Self efficacy}

\section{Model Summary}

\begin{tabular}{|c|c|c|c|c|c|c|c|c|c|}
\hline \multirow{2}{*}{$\begin{array}{l}\text { Mod } \\
\text { el }\end{array}$} & \multirow[t]{2}{*}{$\mathrm{R}$} & \multirow{2}{*}{$\begin{array}{c}\mathrm{R} \\
\text { Squa } \\
\text { re }\end{array}$} & \multirow{2}{*}{$\begin{array}{c}\text { Adjusted R } \\
\text { Square }\end{array}$} & \multirow{2}{*}{$\begin{array}{l}\text { Std. Error of } \\
\text { the Estimate }\end{array}$} & \multicolumn{5}{|c|}{ Change Statistics } \\
\hline & & & & & $\begin{array}{l}\text { R Square } \\
\text { Change }\end{array}$ & $\begin{array}{c}\mathrm{F} \\
\text { Change }\end{array}$ & $\begin{array}{l}d \\
f \\
1\end{array}$ & $\begin{array}{l}\mathrm{d} \\
\mathrm{f} \\
2\end{array}$ & $\begin{array}{c}\text { Sig. F } \\
\text { Change }\end{array}$ \\
\hline 1 & $\begin{array}{r} \\
5 \\
3 \\
\mathrm{a}\end{array}$ & .35 & .32 & 35.48 & .35 & 2.21 & 5 & $\begin{array}{l}8 \\
6\end{array}$ & .05 \\
\hline 2 & $\begin{array}{c}\dot{5} \\
4 \\
\mathrm{~b}\end{array}$ & .36 & .33 & 35.63 & .01 & .29 & 1 & $\begin{array}{l}8 \\
5\end{array}$ & .04 \\
\hline
\end{tabular}

a. Predictors: (Constant), Demands for hiding emotions, Work pace, Emotional demands, Quantitative demands. b. Predictors: (Constant), Demands for hiding emotions, Work pace, Emotional demands, Quantitative demands, Personality (Self efficacy).

\section{Dependent Variable: Job satisfaction \\ Model 1 (without the Moderator)}

It is found from the model summary $R(0.53), R^{2}(0.35)$ and $F(2.21)$ value explains that there is causal relationship between predictors independent variables (job demands) and dependent variable (job satisfaction). These value indicates that the correlation between predictors job demands and job satisfaction is significant and the linear regression of job satisfaction on job demands is also significant. It means job satisfaction is cause-andeffect of job demands.

\section{Model 2 (with the Moderator)}

The changed $R^{2}(0.01)$ and $F(0.29)$ value from model summary indicating that there is potentially significant moderation between job demands and job satisfaction on personality trait (self efficacy) and hence the proposed model is highly significant.

\section{FINDING AND DISCUSSION OF THE STUDY}

The findings of this study reveal that correlation exists in between variables of job demands and its various effect (for ex; burnout, stress, sleeping troubles, depressive symptoms and job satisfaction). Moderating effects of personality trait (in this study it is self efficacy) between job demands and its various effect on health also exists. However, there was no direct correlation found between many variables of this study, but these variables are indirectly correlated with those variables have no direct correlation. For ex; self-efficacy was not directly correlated with sleeping troubles and burnout; but correlated through stress. Because self-efficacy was directly correlated with stress and stress was correlated with sleeping troubles and burnout. In this way it was found that variables of this study were correlated with each other either directly or indirectly.

The findings from this study suggest that contending with stressful situations in the workplace is a common occurrence for the Indian loco pilots (railway drivers) leading to deterioration in their quality of work and life. These are the important reasons to assume that sleepiness and stress reduce a railway driver's mental capacity when work load reach its peak. In particular irregular and night work is a further stress factor for the loco-pilots due to its negative effects on various aspect of their lives, in particular as concerns:

1. Disturbances of the normal biological rhythms, beginning with the sleep/wake cycle;

2. Negative effects on health and well-being, including troubles with the digestive function, nervous system (sleep deficit, anxiety, depression) and cardiovascular systems (heart diseases);

3. Social problems, resulting from difficulties in maintaining the usual relationships both at the family and social levels.

\section{SUGGESTIONS AND RECOMMENDATIONS}

Following points are concluded from the theoretical part of this paper. The aim of these points is to suggest possible solutions and tools how to improve work environment of loco pilots (railway drivers) in India, in order to reduce the stress caused by different factors.

1. In order to keep the employees on the track of success and retain them for the benefit of organization, the organization must chart out a proper career planning policy which ensures the employees about their career growth and recognition.

2. It is also suggested that the management of organization must undertake stress audit at all levels of the organization to find out stressful areas of job to take necessary action for their elimination or overall 
improvement of job. The next step of this study would involve collecting data from a larger sample of Indian loco pilots (railway drivers) and then test the proposed conceptual model of this study.

\section{REFERENCES}

[1] Bakker, A. B., and Demerouti, E. (2007). The job demands-resources model: State of the Art. Journal of Managerial Psychology, Vol. 22(3), 309-328.

[2] Bandura, A. (1977). Self-efficacy: towards a unifying theory of behavioral Change. Psychological Review, Vol. 84, 191-215.

[3] Carayon, P. (1993). Effect of electronic performance monitoring on job design and worker stress: Review of the literature and conceptual model. Human Factors, Vol. 35, 385-95.

[4] Cox, T., Griffiths, A. and Rial-Gonzalez, E. (2000). Research on Work-Related Stress. Office for Official Publications of the European Communities: Luxembourg.

[5] Dorn, L. (2003). Driver behaviour and training. Ashgate Publishing Limited, England.

[6] European Agency for Safety and Health at Work (2000). Future occupational safety and health research needs and priorities in the member states of the European Union. Luxembourg: Office for Official Publications of the European Communities; 2000.

[7] FIRE Quartly Magazine (Aug., 2012). All India Loco Running Staff Association.

[8] International Labour Office Governing Body 312th Session, Geneva, November 2011.

[9] Johnson JV. (1989). Control, collectivity and the psychosocial work environment. In: Sauter S, Hurrell J, Cooper C, editors. Job stress and work control. London: Wiley, 55-74.

[10] Karasek, R.A. (1979). Job demands, job decision latitude, and mental strain: implications for job redesign. Administrative Science Quarterly, Vol. 24, 285-308.

[11] Karasek R and Theorell T. (1990). Healthy work: stress, productivity and the reconstruction of working life. New York (NY): Basic Books; 1990.

[12] Kristensen TS, Pejtersen JH, Borg V and Bjorner JB. (2010). The second version of the Copenhagen Psychosocial Questionnaire (COPSOQ II). Scand J Public Health, Vol. 38 (Suppl 3), 8-24.

[13] Perrewe, P. L., and Zellars, K.L. (1999). An examination of attributions and emotions in the transactional approach to the organizational stress process. Journal of Organizational Behavior, Vol. 20, 739-752.

[14] Ranjan Rajesh and T. Prasad (2013). Literature Review Report on - An Analytical Study on Working Conditions of Loco-Pilots (Railway Drivers) in India. European Journal of Business and Management (EJBM). Vol.5, No.12.

[15] RDSO (1997), Report No. PTD 3, Lucknow: Research Design and Standard Organization. Psycho Technical Directorate, Ministry of Railways; 1997.

[16] Schaufeli, W. B., and Bakker, A. B. (2004). Job demands, job resources, and their relationship with burnout and engagement: a multi-sample study. Journal of Organizational Behaviour, Vol. 25, 293-315.

[17] Shirom, A., Melamed, S., Toker, S., Berliner, S., and Shapira, I. (2005). Burnout and health review: Current knowledge and future research directions. International Review of Industrial and Organizational Psychology, Vol. 20, chap. 7.

[18] Singh Ravi Kant, (2008). Life of an Assistant Loco Pilot (ALP)/Assistant Driver. All India Loco Running Staff Association (Downloaded from Google, 2013).

[19] Strahan, C., Watson, B., and Lennonb, A. (2008). Can organizational safety climate and occupational stress predict work-related driver fatigue? Transportation Research, Part F 11, 418-426.

[20] Sullivan, S.E., and Bhagat, R.S. (1992). Organizational stress, job satisfaction and job performance: where do we go from here? Journal of Management, Vol. 18, 353-374.

[21] Varca, P. E. (1999). Work Stress and Customer Service Delivery. Journal of Services Marketing, Vol. 13(3), 229-241.

[22] Warr, P.B. (1990). Decision latitude, job demands, and employee wellbeing. Work and Stress, Vol. 4, 285-294.

[23] WHO (1948). Official record of the World Health Organization No 2, June, 1948, New York.

[24] WHO (1986). The Ottawa Charter for Health Promotion, 1986. World Health Organization.

[25] WHO (2005). A Report of the World Health Organization, Department of Mental Health and Substance Abuse. in collaboration with the Victorian Health Promotion Foundation and The University of Melbourne, Editors: Helen, Herrman, Shekhar Saxena, Rob Moodie@ 2005. 